\title{
Household Inward Remittances And Productive Investment In Nigeria: A Multidimensional Analysis
}

\author{
Prof. John Emeka Ezike \\ Department of Finance \\ University of Lagos, Nigeria \\ Charles Ogboi Ph.D \\ Department of Economics, Accounting \& Finance \\ Bells University of Technology, Ota Nigeria
}

\begin{abstract}
There has been an unprecedented inflow of household inward remittances into the Nigerian economy over the recent years however there are concerns about the use of inward remittances for productive investment or consumption of imported goods. This study sought to empirically examine the effect of household inward remittances on productive investments in Nigeria. Generalized Method of Moment (GMM) estimator was used to analyze time series data sourced from World Development Indicators (WDI) 2015 edition. Results showed that; (i) inward remittances have negative and significant impact on productive investment in Nigeria, $(\eta \dot{\eta}=-0.0617 ; p=0.0279)$ (ii) inward remittances have positive and significant impact on consumption (' $\Omega=0.0330$; $\mathbf{p}=0.0365$ ), (iii) Consumption exert positive and significant impact on imported goods ( $\lambda=1.018 ; p=0.0241)$. The study therefore concluded that inward remittances discourage productive investment and boost consumption of imported goods. This could be attributed to the seeming resource transfer to consumption of imports arising from price differentials between locally manufactured goods to foreign imports. To plug this leakage, it becomes imperative for Nigerian government to dismantle all bureaucratic bottlenecks that make cost of production high. It is recommended that Nigerian government should begin to build infrastructure and subsidize production as against subsidizing consumption such as proposed school feeding and fuel Subsidy
\end{abstract}

Keywords: inward remittances, investment, consumption GMM, Nigeria

\section{INTRODUCTION}

Household inward remittances as private monetary transfers by migrants to their home countries have increased substantially in recent times. Inward remittances to developing countries reached \$430bn in 2011 from \$333bn in 2010(World Bank 2012). World Bank(2013) forecasts that it would increase to about $\$ 500$ bn by 2015 . Remittance inflow into Nigeria has surpassed other foreign exchange flows like Foreign Direct Investment (FDI) and Official Development Assistance (ODA) both in absolute terms and as percentage of GDP (World Bank, 2012)

In the case of Nigerian economy, available data from Central Bank of Nigeria CBN (2015) and World Bank (2014) show that inward remittances averaged \$20bn per annum from 2005 to 2013, yet outlays on additions to the fixed assets of the economy plus net changes in the level of inventories remained low in corresponding period. The banking system is still characterized by many small and uncompetitive banks as indicated by low ratio of credit to private sector to GDP at 36.89\%, money supply to GDP averaging 38.7\% in the corresponding period. Besides, the gross domestic product growth rate has been hovering between 6-7\% in the past ten years. 
These statistics are still the same when compared to the period before the upsurge of remittance inflow.

Remittances have been receiving research attention from both people in academics and policy makers. This increased research attention could be attributed to empirical evidences suggesting that inward remittances remain an important source of investment finance for individuals and families to cope with poverty and economic crisis.

Abdih, Chami, Dagher, and Montiel (2012), observed that inward remittances help improve household welfare by lifting families out of poverty and insuring them against income shocks. Adams and Page (2005); Chami, Barajas, Cosimo, Fullenkamp, Gapen, and Montiel (2008);), Catteneo (2008) posit that households that receive remittances spend less on consumption and more on investment, while Kalim and Shahbaz (2009) see remittances as useful means for poverty reduction.

Although empirical evidence suggest remittance could be potential source of investment finance especially in Asian countries, whether or not it has altered the investment climate in the case of Nigeria is still being debated. There are several studies that document the volume of remittance inflows, but how these funds are used is still an open question among financial economists. In search of the channel(s) through which remittances affect growth Aggarwal Asli, and Mari (2006); Giuliano and Ruiz-Arranz (2009); and Gupta, Pattillo, and Wagh (2009) examined the relationship amongst remittances, financial development and economic growth, and produced mixed results. According to Ziesemer(2007), inward remittances can affect the rate of capital accumulation in recipient economies in various ways. First, they can directly finance investment. Remittance inflows can also facilitate the financing of investments by improving the creditworthiness of households, effectively augmenting their capacity to borrow. Remittances may also reduce the risk premium that lenders demand, because they reduce output volatility. But if remittances are perceived to be permanent income, households may spend them rather than save them significantly reducing the amount of flows directed to investment. And, in fact, the amount of remittances devoted to investment tends to be low. For example, remittance flows into the Middle East and North Africa region fuel the consumption of domestic and foreign goods, with very little going to investment. In addition, many households save part of the remittances by purchasing assets such as real estate, which generally does not increase the capital stock.

The objective of this study is to establish the effect of inward remittances on productive investments in Nigeria.

The rest of this study is structured as follows: Apart from this introductory section, section two contains the theoretical framework, section three contains empirical literature, while section four and five contains result/discussion and conclusion and recommendation respectively.

\section{Theoretical Review}

\section{LITERATURE REVIEW}

The raging debate about the macro-economic impact of inward remittances on the recipient economy is inconclusive and produced three distinct schools of thought.

i. The remittance optimist school

ii. The remittance pessimist school

iii. The middle of the road approach 
The remittance optimist school believed that inward remittances influence consumption and investment to impact on recipient economy's growth and development. (Habib, 1985; Burney, 1989; Aseh, 1994; Taylor 1999).

Positive effects of inward remittances occur as a result of numerous benefit that accrue to remittances recipient households and non-recipient households. Inward remittances mitigate income risk, improve housing, education and health, financing investment and improves infrastructural facilities such as schools. Stark and Bloom (1985) Taylor (1999), Stark (1991) also support the remittance optimist school. Meanwhile, De Haas (2007) raise the issue of public moral hazard of inward remittances. De Hass (2007) observed that government institutions of recipient country could abdicate their fiduciary responsibility while the citizenry look the other way as a result of remittance inflows.

Edwel Jr. (2010) also argued that remittance inflow could cause exchange rate appreciation that could cause Dutch disease syndrome.

The term "Dutch disease" is a situation that occurs when a country's apparent good economic fortune ultimately proves to exert a net detrimental effect.

Previous research in other countries such as Pakistan, Bangladesh, Korea, Philippines, Ireland and Mexico found that inward remittances are associated with positive output growth (Burney 1989; Aseh, (1994), Kim (1983:1986) found that between 3.0 percent and 7.0 percent of 19761981 GNP growth in South Korea was attributable, directly and indirectly to migrant remittances.

Corroborating the view of Kim (1983; 1986), Fayissah and Nsiah (2008) in a survey of African countries found that migrant remittances boost output growth in countries where the financial system are less developed by providing alternative source of financing investment and helping micro entrepreneurs overcome liquidity constraints.

In contrast, Catrinescu et al (2006; Thanh Le (2008) posit that migrant remittances could only impact economic growth, if regulatory authorities formulate and implement appropriate economic policies that encourage productive investment. They based their argument on New Economics of Labour Migration (NELM).

\section{Empirical Review}

Several authors have studied the nature of relationship that exist among inward remittances, investment and consumption in both developed and developing countries. Evidence from these revealed conflicting results with varying magnitude and direction. Hrushikesh (2008) examined the impact of remittances on macroeconomic activities (private consumption and investment) and its implications on economic growth in India for the period from 1966-67 to 2003-04. The authors developed a framework for examining the impact of remittances on private consumption, investment and output growth in a nested approach (combination of standard Keynesian and Neo classical framework). In their study, the authors considered remittances to be an addition to the domestic income that result into increased consumption, and that once consumption is satisfied, the leftover of remittances will then be invested. The authors posit that if remittances are channeled into real investment, it could stimulate output growth. In this study, the authors hypothesize that private consumption depends on income, wealth, private transfers, rate of interest, and openness of the economy. Similarly, Private investment is assumed to depend on user cost of capital, availability of bank credit and funds 
available from other resources, as well as openness of the economy. On the other hand, economic growth is hypothesized to depend on gross private sector investment, openness of the economy, fiscal policy and rate of interest. The equations specified under their so- called nested approach are:

\section{Private Consumption Model}

$$
\mathrm{C}=\stackrel{\alpha}{\alpha}_{1} \mathrm{Y}+\dot{\alpha}_{2} \mathrm{~W}+\dot{\alpha}_{3} \mathrm{R}+\dot{\alpha}_{4} \mathrm{REM}+\dot{\alpha}_{5} \mathrm{EXMPCA} / \mathrm{GDP}+\dot{\alpha}_{6} \mathrm{Z}+\mathrm{u} \text {. }
$$

Where $\mathrm{C}$ is private consumption in the domestic market; $\mathrm{Y}$ is income /output; $\mathrm{W}$ is wealth; $\mathrm{R}$ is interest Rate; REM is remittances; EXMPCA/GDP is openness; $\mathrm{Z}$ is other variables (public expenditure)

\section{Private Investment Model}

$$
\mathrm{I}=\beta_{1} \mathrm{Y}+\beta_{2} \mathrm{UCC}+\beta_{3} \mathrm{REM}+\beta_{4} \mathrm{EXMPCA} / \mathrm{GDP}+\beta_{5} \mathrm{GDB}+\beta_{6} \mathrm{Z}+\mathrm{e} .
$$

Where I is private Investment; $\mathrm{Y}$ is output; UCC is user cost of capital; EXMPCA/GDP is openness; GDB is government domestic borrowings; $\mathrm{Z}$ is control variables such as bank credit, government expenditure and others

\section{Economic Growth model}

$$
\mathrm{Y}=\psi_{1} \mathrm{l}+\psi_{2} \text { EXMPCA } / \text { GDP }+\psi_{3} \mathrm{REM}+\psi_{4} \mathrm{GBORR}+\psi_{5} \mathrm{R}+\psi_{6} \mathrm{Z}+\psi_{7} \mathrm{Z}+\mathrm{e}
$$

Where $\mathrm{Y}$ is growth rate of output; I is growth rate of investment; EXMPCA/GDP is openness; $\mathrm{R}$ is rate of interest; $\mathrm{Z}$ is set of control variables

Using data mainly sourced from Reserve Bank of India, Ministry of Finance and Central Statistical Organization (CSO), the authors employed Error Corrections Model and Dynamic Ordinary Least Square (DOLS). Findings from the study indicate that remittances in conjunction with debt, money supply (net of bank demand deposits) and income, have a positive impact on private consumption and remittances have adverse effect on private investment but no effect on economic growth. The authors could not probe further or explain why remittance that produced positive and significant effect on private consumption did not exert any influence on economic growth.

Tansel and Yasar (2010) estimates a Keynesian simultaneous dynamic macroeconomic model to examine whether remittance inflows into Turkish economy impact on key macroeconomic variables such as consumption, investment, imports and income. The authors adopted a modified version of glystsos (2002a, 2002b and 2002c) model that allows determination of the short-run and long-run effects of an exogenous shock of remittances on selected key macroeconomic variables. The authors presented their model as:

$$
\begin{aligned}
& \mathrm{Ct}=\alpha_{0}+\alpha_{1} \mathrm{Y}_{\mathrm{t}}+\alpha_{2} \mathrm{C}_{\mathrm{t}-1 \ldots \ldots \ldots \ldots} \ldots \ldots \ldots \ldots \\
& \mathrm{I}_{\mathrm{t}}=\beta_{0}+\beta_{1} \mathrm{Y}_{\mathrm{t}}+\beta_{2} \mathrm{~K}_{\mathrm{t}-1 \ldots \ldots \ldots \ldots \ldots \ldots} \\
& \mathrm{M}_{\mathrm{t}}=\delta_{0}+\delta_{1} \mathrm{Y}_{\mathrm{t}}+\delta_{2} \mathrm{M}_{\mathrm{t}-1 \ldots \ldots \ldots \ldots \ldots} \\
& \mathrm{Y}_{\mathrm{t}}=\mathrm{Kt}+\mathrm{Gt}+\mathrm{E}_{\mathrm{t}}+\mathrm{M}_{\mathrm{t}}+\mathrm{R}_{\mathrm{t}}+\mathrm{SDt}
\end{aligned}
$$

Where, $\mathrm{Y}$ is the sum of GDP and remittances (R); $\mathrm{K}$ is the cumulative gross domestic investment; $\mathrm{G}$ is the government consumption expenditure; SD is the statistical discrepancy; $\mathrm{T}$ is the time. According to the authors, C.I, M and Y are endogenous variables where investment is assumed to be a positive function of income as a proxy of profits and a negative function of lagged capital stock. The authors adopted Two stage Least Squares (TSLS) method that are consistent and efficient as opposed to Ordinary Least Squares (OLS) estimates that are biased 
and inconsistent because of possible correlation between explanatory endogenous variables and the error terms. Empirical evidence from the study suggests that remittances have contributed positively to the development of Turkish economy. Adams, Cuecueha and Page (2009) used 2005/2006 nationally representative household survey in Ghana to analyze how the receipt of internal remittances from Ghana and international remittances (from African or other countries) affect the marginal spending behavior of households on various consumption and investment goods. The authors did a detailed comparative analysis of Ghanaian households that receive remittances and households that do not receive remittances. They noted that the heterogonous characteristics of these household could bias the result and therefore addressed this concern by using a Two Stage Multinational Logit Ordinary Least Squares (OLS) procedure to test for selection bias in the household receipt of remittances. Empirical evidence from thier study produced two intriguing results. On the average, households receiving international remittances spend $14 \%$ less at the margin on food than what they would have spent without receipt of remittances. Households that receive both internal and external remittances spend between 3\% and 33\% or more at the margin, respectively, on education than what they would have spent on investment good without the receipt of remittances.

Chilokwu, Olise and Ewuim (2011) explored the human rights of Nigerian migrants and analyzed the contributions of migrant remittances to income generation in Nigeria. In their study, the authors traced the size and importance of migrant remittances in developing countries and noted that remittance represent high quality resource because of their economic and social dimensions, as well as the transfer of know how that accompanies remittance inflows. They agreed with Ratha et al., (2011) that migration in Africa has important effects on social issues that cannot be evaluated purely in economic terms. The authors therefore analyzed the cost and benefit of migrant remittances on gender and family cohesion. In examining the trend of remittance inflows to selected African countries for the period, 2006 to 2010 , using data from World Bank, the study revealed that in 2006, the sum of $\$ 5.435$ billion was remitted from abroad to Nigeria. From 2007 to 2009, the sum of $\$ 9,221$ billion, $\$ 9,980$ and $\$ 9,585$ billion respectively were remitted to Nigeria by Nigerian migrants. In 2010, an estimated amount of $\$ 9,975$ billion was also remitted to Nigeria. The authors linked these inflows to microfinance development in Nigeria, and consumption expenditure enhancement of households. Furthermore, the study revealed that remittances are mostly spent on essential consumption, investment in physical and human capital expenditures that improve welfare and productivity.

Olowa and Awoyeni (2012) extended the debate about how remittances are spent or used and their impact on economic development using the Nigeria Living Standard Survey 2004 datasets. The authors noted that while prior studies have focused on the impact of remittances on household investment in Nigeria, empirical study on the effect of remittances on household expenditure is lacking, which prompted the need for their study. Adopting Adams (2005) econometric model, the authors separated remittance receiving and non receiving households and then analyzed their marginal expenditure patterns of rural households in Nigeria. In adopting this model, the authors ensured that, one, it provided a good statistical fit to a wide range of goods; second, it has a slope that is free to change with expenditure -consumption relationship; lastly, it conforms to the criterion of additivity such that sum of the marginal propensities for all goods equal unity. Empirical findings from this study produced three startling revelations, first, that contrary to other studies, it was revealed that majority of remittance earnings are spent on consumption goods; second, that the marginal spending behavior of households receiving remittances is qualitatively different from that of households 
which do not receive remittances; third, that at the margin, households that receive domestic and international remittances spend $15.3 \%$ and $2.2 \%$ respectively, on housing than households that do not receive remittance.

Olubiyi (2013) argued that while Nigeria has been experiencing continuous inflows of workers' remittances over time, the level of investment is still low. The evidence showed that there is a direct and positive relationship between financial development and investment on the one hand and governance institution and investment on the other hand. He further stated that all things being equal, sound and functioning financial institution should reduce credit constraints and provides access to credit for the existing and potential investors, thereby raising investment level of the country. On the contrary, in a country where financial development is shallow, access to credit will be difficult and such credit constraints could hamper investment.

In an attempt to obtain a clearer picture of the importance of remittance on investment climate in Nigeria, Olubiyi (2013) specified an investment function as:

$$
\mathrm{INV}_{\mathrm{t}}=\left(\mathrm{rem}_{\mathrm{t}}, \text { inst }_{\mathrm{t}}, \mathrm{mp}_{\mathrm{t}}, \mathrm{rem}_{\mathrm{t}}{ }^{*} \text { inst }_{\mathrm{t}}, \mathrm{X}\right)
$$

Where, INV is private investment, REM represents workers remittances, INST is a measure of institutional quality, MP is monetary policy instrument and $\mathrm{X}$ represents other control variables that could affect investment. Upon the estimation of the investment model using GMM-IV estimator it was found that remittances will only affect investment positively if governance institutions are right.

Ojapinwa and Odekunle (2013) noted that the role of remittances on private investment is still inconclusive, and therefore examined whether or not the level of financial depht in Nigeria affect impact of remittances on capital formation. Employing stock and Watson (1993) Dynamic Ordinary Least Squares (DOLS), the authors empirically examined the impact of remittance on investment and also dynamic interaction with financial development in Nigeria over the period 1977 to 2010. Empirical results indicate that remittances have significant effect on investment. The authors interpret this findings to mean that remittances can bring about more growth if financial sector is more developed in addition to other incentive that can help stimulate growth.

Overall, review of extant literatures showed that the actual nature of the relationship amongst remittances, investment and consumption vary from country to country. While remittances enhance investment in some countries, it is not very good news in some counties. The above scenarios suggest that certain factors must come to play for remittance to boost investment.

It is therefore imperative that a robust study of this nature be carried out to examine whether or not household inward remittances help boost investment or otherwise

\section{ANALYTICAL FRAMEWORK AND MODEL SPECIFICATIONS}

The Generalized Method of Moment (GMM) proposed by Hansen (1982) is adopted for this study. The GMM estimator is more robust and dynamic, as it allows the regressor variables to depend on its past values. The attractiveness of GMM over other estimators like Ordinary Least Squares (OLS) and two Stage Least Squares (2TSLS) is the possibility of obtaining consistent point estimates in the presence of heteroscedasticity, serial auto correlation and non linearity (White, 1984; Newey \& West, 1987). The 2TSLS uses a weighting matrix constructed under homoscedasticity while GMM estimator allows for the parameters to be over- identified (Craig, 1983).The application of GMM to time series estimation has some attractive features. First, it avoids the need to specify distributional assumptions such as normal errors. Second, it 
provides a unifying framework for the analysis of many familiar estimators such as Ordinary Least Squares (OLS), Instrumental Variable (IV). Third, it offers a robust method of estimation in a situation where the traditional method appears computationally cumbersome. Fourth, it affords the opportunity to specify an economically interesting set of moments, or a set of moments believed to be robust to misspecifications of the economic or statistical model (Kenedy, 2003).

\section{Model Specifications}

In line with the theoretical framework of this study, inward remittances can affect the rate of capital accumulation in recipient economy in several ways, first, they can directly fiancé productive investment, inward remittances can also facilitate the financing of investments by improving the creditworthiness of households. The can also reduce the risk premium that banks demand. In order to subject these postulations into empirical test, model one below is stated.

LOGINV $=\dot{\eta}_{0}+\mathrm{n}_{1}$ LOGINV $_{\mathrm{t}-1}+\dot{\eta}_{2}$ LOGREM $_{\mathrm{t}}+\dot{\eta}_{3}$ LOGCPS $_{\mathrm{t}}+\dot{\eta}_{4}$ LOGFINC $_{\mathrm{t}}+\dot{\eta}_{5}$ LOGLENDR $_{\mathrm{t}}+$ $\eta_{6} \mathrm{LOGINF}+\mu \mathrm{t}_{4}$

Where, LOGINV is the natural logarithm of investment; LOGINV $\mathrm{t}_{\mathrm{t}-1}$ is the one period lagged of natural logarithm of productive investment; LOGREM is the natural logarithm of household inward remittances; LOGCPS is the natural logarithm of credit to private sector; LOG(REM * CPS) is the natural logarithm of interaction between remittances and private sector credit; LOGLENDR is the natural logarithm of lending rate; LOGGDP is the natural logarithm of gross domestic product; $\mathrm{t}$ is the time period from 1977 to $2014 ; \eta_{0}$ is the intercept $\dot{\eta}_{1}-\eta_{6}$ are parameters to be estimated

\section{a priori expectations}

$\dot{\eta}>0, \dot{\eta}_{2}<>0, \dot{\eta}_{3}>0, \dot{\eta}_{4}<>0, \dot{\eta}_{5}>0, \dot{\eta}_{6}>0$

Meanwhile review extant literature suggests that a large proportion of inward remittances to Sub Sahara Africa and Nigeria in particular may have been channeled into conspicuous consumption. In order to explore the consumption channeled into conspicuous consumption. In order to explore the consumption channel of remittance inflows we specify consumption model as:

$$
\text { LOGFINC }_{t}={ }^{\prime} \Omega_{0}+{ }^{\prime} \Omega_{1} \text { FINC }_{\mathrm{t}-1}+{ }^{\prime} \Omega_{2} \text { LOGREM }_{\mathrm{t}}+{ }^{\prime} \Omega_{3} \text { DEPR }_{\mathrm{t}}+{ }^{\prime} \Omega_{4} \mathrm{LOGGDP}_{\mathrm{t}}+\mu \mathrm{t}_{5} \ldots \ldots \text { (3.2) }
$$

Where LOGFINC is the natural logarithm of final consumption expenditure; LOGFINC $\mathrm{t}_{\mathrm{t}-1}$ is the natural logarithm of one period lagged of final consumption expenditure; LOGREM is the natural logarithm of household inward remittances; LOGDEPR is the natural logarithm of deposit rate; LOGGDP is the natural logarithm of gross domestic product; $t$ is the time period from 1977 to 2014 ; ' $\Omega_{0}$ is the intercept; ' $\Omega_{1} \ldots \ldots . . .{ }^{\prime} \Omega_{4}$ are parameters to be estimated; $\mu \mathrm{t}_{\mathrm{s}}$ is the error term

\section{a priori expectations}

$\Omega_{1}>0,{ }^{\prime} \Omega_{2}<>0,{ }^{\prime} \Omega_{3}>0,{ }^{\prime} \Omega_{4}>0$

Considering the consumption pattern of Nigerians that is Skewed towards imports as a result of exorbitant price of domestically manufactured goods, it is imperative to ascertain whether 
remittance receipts has been channeled into consumption of imported goods. It is based on this that model 3 is formulated thus:

LOGIMPT $_{\mathrm{t}-1}=\lambda_{0}+\lambda_{1}$ LOGIMP $_{\mathrm{t}-1}+\lambda_{2}$ LOGGDP $_{\mathrm{t}}+\lambda_{3}$ LOGREER $_{\mathrm{t}}+\lambda_{4}$ LOGLENDR $_{\mathrm{t}}+\lambda_{5}$ LOGOPEN + $\mathrm{LOGREM}_{\mathrm{t}}+\lambda_{7} \mathrm{LOG} \mathrm{FINCt}_{+} \mu \mathrm{t}_{6}$

Where, LOGIMPT is the natural logarithm of imports; LOGIMPT $\mathrm{t}_{\mathrm{t}-1}$ is the natural logarithm of one period lagged value of; LOGGDP is the natural logarithm of gross domestic product; LOGLENDR is the natural logarithm of bank lending rate; LOGOPEN is the natural logarithm of trade openness; LOGREM is the natural logarithm of remittance inflows; LOGFINC is the natural logarithm of final consumption expenditure; $t$ is the time period from 1977 to $2014 ; \lambda_{0}$ is the intercept; $\lambda_{1} \ldots . . \lambda_{7}$ are the parameters to be estimated; $\mu_{\mathrm{t} 6}$ is the error term.

\section{a priori expectations}

$\lambda_{1}>0, \lambda_{2}<0, \lambda_{3}<0, \lambda_{4}<0, \lambda_{5}<>0, \lambda_{6}<>0$,

\section{Descriptive Statistics}

\section{RESULTS AND DISCUSSION}

The descriptive statistics in table 1 below show that inflation rate has the lowest mean rate of 0.0820 while logarithm of consumption expenditure exhibits the maximum mean rate of 2.8987. Natural logarithm of investment, remittances, banking development and lending rate exhibit mean values of $1.6756,-0.3643,1.7830$ and 2.777 respectively.

The maximum values of the series, investment, remittances, consumption, banking development, inflation rate and lending rate are 2.35, 2.25, 3.10, 2.47, 43.22 and 3.45 respectively and minimum values of $1.03,-3.61,2.65,1.37,-43.57$ and 2.12 respectively.

Table 1: Descriptic Statistics

\begin{tabular}{|c|c|c|c|c|c|c|}
\hline & DLOGINV & DLOGFINC & DLOGREM & DLOGCPS & DINF & DLOGLEND \\
\hline Mean & 1.6756 & 2.8987 & -0.3643 & 1.7830 & -0.0820 & 2.7777 \\
\hline Median & 1.6241 & 2.9107 & 0.5761 & 1.7260 & 0.3200 & 2.8791 \\
\hline Maximum & 2.3560 & 3.1098 & 2.2533 & 2.4791 & 43.2200 & 3.4563 \\
\hline Std Dev & 0.3664 & 0.0996 & 1.8047 & 0.2754 & 16.0078 & 0.1282 \\
\hline Skewness & 0.4597 & -0.3479 & -0.3347 & 0.9043 & -0.3605 & 0.3678 \\
\hline Kurtosis & 2.3643 & 3.5726 & 1.5953 & 3.5533 & 5.5186 & 09.5365 \\
\hline Jarque-Bera & $1.8223^{*}$ & $1.1846^{*}$ & $3.5308^{*}$ & $5.2176^{*}$ & $9.9595^{*}$ & $2.5976^{*}$ \\
\hline Prob. & 0.4020 & 0.5530 & 0.1711 & 0.0736 & 0.0068 & 0.2728 \\
\hline Obs & 35 & 35 & 35 & 35 & 35 & 35 \\
\hline
\end{tabular}

SOURCE: Authors computation from E-view 7, 2017

NOTE: Critical values of $\mathrm{X}^{2}$ at $5 \%$ and $1 \%$ levels are 5.99 and 9.21 respectively, ${ }^{*}(* *)$ denotes acceptance of the null hypothesis that variables are normally distributed at the 5\% (1\%) significant level.

The Skewness is a measure of the departure of a distribution from symmetry. A distribution that is not symmetrical is said to be asymmetrical. The result in table 1 indicates that almost all the series are negatively skewed except investment, banking development and lending rate that is positively skewed.

Kurtosis result which measures the degree of peakedness of a distribution in relative terms to a normal distribution indicates that investment, remittances and lending rate are platykurtic $(\mathrm{R}<3)$, while consumption expenditure, banking development, and inflation are leptokurtic ( $\mathrm{r}$ 
>3).The Jarque-Bera statistic shows that all the series are normally distributed expect inflation rate.

\section{Unit Root Test and Cointegration Test \\ Unit Root Test}

Table 2 below show the null hypotheses that a variable under investigation has a unit root, against the alternative that it does not, cannot be rejected for all the data series in their levels at either the 1\% and 5\% significance level. Having taken the first difference of all the series, the ADF and PP test was further employed in testing for the stationarity of these differenced series.

The series tested are: LOGGDP, LOGREM, LOGREM, LOGCPC, LOGINV, POP, LOGSECENR, LOGOPEN, LOG(REM*CPS), INF, LOGLENR, LOGREER, \& LOGFINC.

The result indicates that some of the variables are stationary at level: LOGCPS, LOGFINC and INF while LOGGDP, LOGREM, LOGINV, POP, LOGSECENR, LOGOPEN, LOG(REM*CPS), LOGLENDR and LOGREER are non stationary at level, but however become stationary after first difference (1).

Given the unit root properties of the variables, it becomes necessary to establish whether or not there is a long run cointegrating relationship among the variables in models one, two, three and four using the Johansen Full Information Maximum Likelihood method.

Table 2: Unit Root Test

\begin{tabular}{|c|c|c|c|c|c|}
\hline \multirow[t]{2}{*}{ Variable } & \multicolumn{3}{|c|}{ ADF ILAG) } & \multicolumn{2}{|c|}{ PP*(3Lags) } \\
\hline & $\begin{array}{l}\text { With constant } \\
\text { (No trend) }\end{array}$ & $\begin{array}{c}\text { With constant } \\
\text { \& Trend }\end{array}$ & $\begin{array}{l}\text { With constant } \\
\text { (No trend) }\end{array}$ & $\begin{array}{c}\text { With constant } \\
\text { \& trend }\end{array}$ & $d^{*}$ \\
\hline LGDP & 0.0996 & -1.1964 & 0.0289 & -1.1964 & $1(1)$ \\
\hline$\Delta \mathrm{GDP}$ & -5.6151 & -5.8907 & -5.6757 & -6.7457 & \\
\hline LREM & $-1.2978 '-$ & -1.4751 & -1.9022 & -2.7758 & $1(1)$ \\
\hline$\triangle$ LREM & 9.8686 & -9.7885 & -9.8686 & -9.7985 & \\
\hline LCPS & -3.7677 & -3.7557 & -3.6187 & -3.5387 & $1(0)$ \\
\hline$\triangle \mathrm{LCPS}$ & - & - & - & - & \\
\hline LINV & -2.6745 & -2.4668 & -2.5170 & -2.2038 & $1(1)$ \\
\hline$\Delta \mathrm{LINV}$ & -6.7618 & -7.4204 & -6.7849 & -9.7470 & \\
\hline $\begin{array}{l}\text { LFINC } \\
\Delta \text { LFINC }\end{array}$ & $\begin{array}{c}-6.6830 \\
- \\
\end{array}$ & $\begin{array}{c}-6.3606 \\
- \\
\end{array}$ & $\begin{array}{c}-6.2479 \\
- \\
\end{array}$ & -6.3871 & $1(0)$ \\
\hline LREMCPS & -1.8279 & -2.4897 & -1.8004 & -2.4897 & $1(0)$ \\
\hline$\triangle$ REMCPS & -7.1707 & -7.1259 & -7.0665 & -7.0231 & \\
\hline $\begin{array}{l}\text { INF } \\
\Delta \mathrm{INF}\end{array}$ & -6.0100 & -5.9546 & -10.7271 & -11.1529 & $1(0)$ \\
\hline LLENDR & -2.3381 & -2.1887 & -2.2319 & $-2 / 0617$ & $1(1)$ \\
\hline$\triangle$ LLENDR & -7.3933 & -6.4429 & -7.5709 & -7.8481 & \\
\hline LREER & -2.1373 & -2.1967 & -2.2125 & -2.3263 & $1(1)$ \\
\hline$\triangle$ LREER & -5.5033 & -5.4594 & -5.4975 & -5.4864 & \\
\hline \multirow{4}{*}{\multicolumn{6}{|c|}{$\begin{array}{l}\text { MCKINNON } \\
\text { CRITICAL } \\
\text { VALUES: } \\
\text { LEVEL }\end{array}$}} \\
\hline & & & & & \\
\hline & & & & & \\
\hline & & & & & \\
\hline \multirow[t]{2}{*}{$1 \%$} & -3.5253 & -4.0928 & -3.5239 & -4.0909 & \\
\hline & -2.9029 & -3.4739 & -2.9023 & -3.4730 & \\
\hline \multirow[t]{2}{*}{$5 \%$} & -3.5267 & $\begin{array}{l}-4.0948 \\
\end{array}$ & -3.5233 & -4.0928 & \\
\hline & -2.9035 & -3.4749 & -2.9029 & -3.4739 & \\
\hline
\end{tabular}

Source: Authors Computation from E-views7, 2017. 
NOTES: ADF, PP, $\mathrm{d}^{*}$ denotes Augmented Dickey Fuller, Phillips-Perron test and decision about the order of integration, respectively.

\section{Cointegration Test}

The coinegration test were undertaken based on Johansen and Juselius (1990) maximum likelihood framework. The essence of this is to empirically establish whether long run relationship exist among the variables. It is establish in literature that multi co integration extends the co integration technique beyond two variables, and this also applies to variables integrated at different orders, (Hatemi, 2008).

Table 3: Co integration Rank Test VARIABLES: LOGINV, LREM, LFINC, LCPS, INF, LLENDR

\begin{tabular}{|c|c|c|c|c|c|}
\hline $\begin{array}{c}\text { Null } \\
\text { Hypothesis }\end{array}$ & $\begin{array}{c}\text { Trace } \\
\text { Statistics }\end{array}$ & $\begin{array}{c}\text { Critical value } \\
\text { @5\% }\end{array}$ & $\begin{array}{c}\text { Null } \\
\text { hypothesis }\end{array}$ & $\begin{array}{c}\text { Max Eigen } \\
\text { statistic }\end{array}$ & $\begin{array}{c}\text { Critical value } \\
\text { @ 5\% }\end{array}$ \\
\hline None* $^{*}$ & 116.8722 & 95.7536 & None & 38.6022 & 40.0775 \\
\hline At most 1 & 78.2699 & 69.8188 & At most 1 & 30.6940 & 33.8768 \\
\hline At most 2 & 47.5759 & 47.8561 & At most 2 & 21.0523 & 27.5843 \\
\hline At most 3 & 26.5235 & 29.7970 & At most 3 & 13.2344 & 21.1316 \\
\hline At most 4 & 13.2890 & 15.4947 & At most 4 & 9.7353 & 14.2646 \\
\hline At most 5 & 3.5537 & 3.8414 & At most 5 & 3.5537 & 3.8414 \\
\hline
\end{tabular}

Source: Authors computation from E-views7, 2017

NOTE: $\left.{ }^{*}{ }^{* *}\right)$ denotes rejection of the hypothesis at 5\% (1\%) significance level..

In model three the trace statistic and maximum eigen statistic did not arrive at the same conclusion. The null hypothesis of at most 1 cointgrating vector (against the alternative of more one vector) is rejected at $5 \%$ level, while the null hypothesis of two cointegrating vectors is accepted at $5 \%$ level in the trace statistic.

\section{GMM Results}

Table 4 report the GMM result of the relationship between inward remittances on productive investment in Nigeria. Estimated result shows that $43 \%$ of change in investment can be explained by the independent variables one year lagged value of investment, inward remittances, consumption, banking sector development, inflation and lending rate.

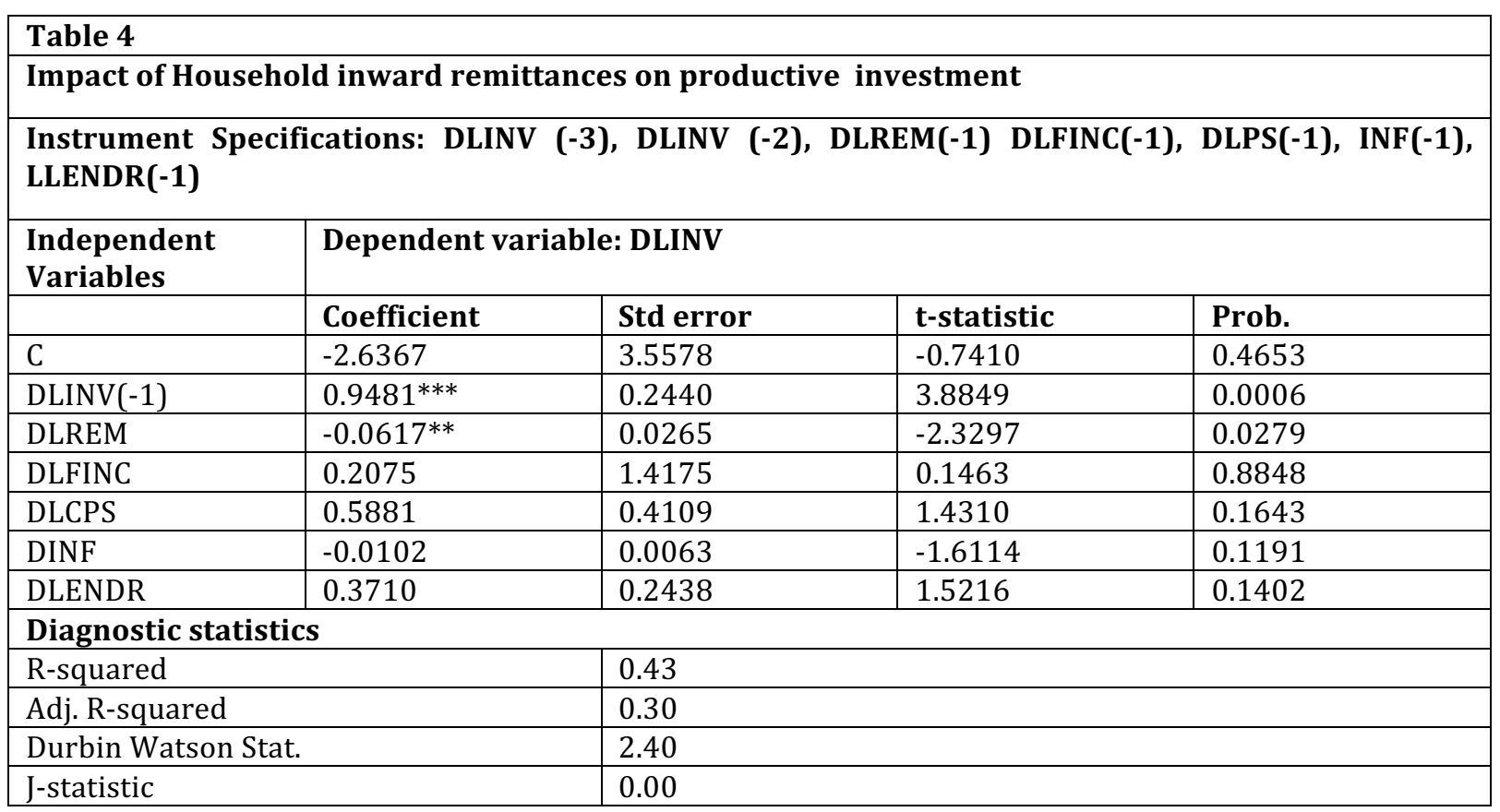

Source: Authors computation from E-view 7, 2017 
Note $: * * *, * *, *$ denotes significance at $1 \%, 5 \%$ and $10 \%$ respectively.

In specific terms, the coefficient of one year lagged investment is positively related to current year investment and statistically significant at 1\%, implying that previous year investment is a strong determinant of current year investment. The coefficient of inward remittances and inflation rate are negatively related to investment. While the coefficient of inward remittances is statistically significant at 5\%, the coefficient of inflation is not statistically significant. In a related development, the coefficients of consumption, banking sector development and user cost of capital are positively related to investment but statistically insignificant.

\begin{tabular}{|c|c|c|c|c|}
\hline Table 5 & \multicolumn{3}{|c|}{ Impact of household inward remittances on consumption expenditure } & \\
\hline \multicolumn{5}{|c|}{ Instrument Specification: LINV 2 , LOGREM2(-1) LOGIMPT2, GDGR2 POP2 } \\
\hline \multirow{2}{*}{$\begin{array}{l}\text { Independent } \\
\text { Variables }\end{array}$} & \multicolumn{4}{|c|}{ Dependent variable: DLFINC } \\
\hline & Coefficient & Std error & t-statistic & Prob. \\
\hline DLFINC(-1) & 0.0833 & 0.4811 & 0.1731 & 0.8637 \\
\hline DLREM & 0.0330 & 0.0150 & 2.1897 & 0.0365 \\
\hline DDEPR & 0.0003 & 0.0065 & 0.0470 & 0.9628 \\
\hline DLGDP & -0.1214 & 0.0593 & -2.0460 & 0.0496 \\
\hline $\mathrm{C}$ & 7.0292 & 2.5608 & 2.7449 & 0.0101 \\
\hline \multicolumn{5}{|c|}{ Diagnostic statistics } \\
\hline \multicolumn{2}{|l|}{ R-squared } & \multicolumn{3}{|c|}{0.20} \\
\hline \multicolumn{2}{|l|}{ Adj. R-squared } & \multicolumn{3}{|c|}{0.10} \\
\hline \multicolumn{2}{|c|}{ Durbin Watson Stat. } & \multicolumn{3}{|c|}{1.88} \\
\hline \multicolumn{2}{|l|}{ J-statistic } & \multicolumn{3}{|c|}{0.01} \\
\hline
\end{tabular}

Source: Authors computation from E-view 7, 2017

Note: $* * *, * *, *$ denotes significance at $1 \%, 5 \%$ and $10 \%$ respectively.

Meanwhile, available data and review of extant literature suggests that substantial amount of remittance inflows may have been channeled into conspicuous consumption. To subject this proposition into empirical test, a consumption model in the presence of inward remittances is specified in model 2. The consumption model from the GMM estimate shows that one year lagged value of consumption DLFINC(-1) have positive relationship with present consumption but statistically insignificant. The coefficient of our focal variable DLREM is positively related to consumption and statistically significant. This implies that holding other variables constant a percentage point increase in remittance inflow will culminate into 0.03 percentage point increase in consumption expenditure in Nigeria. The coefficient of deposit rate (DDEPR) showed positive but statistically insignificant relationship with consumption.

An interestingly finding in this result is the negative and statistically significant relationship effect fond between economic growth and consumption expenditure in Nigeria against a priori expectation. 


\begin{tabular}{|c|c|c|c|c|}
\hline \multicolumn{5}{|c|}{ Impact of inward remittances on imports } \\
\hline \multicolumn{5}{|c|}{$\begin{array}{l}\text { Instrument Specifications: DLIMPT (-2), C, DLREER (-2), DLGDP, DLENDR (-2), DLOPEN (-2) DLREM } \\
\text { (2), DLFINC(-2) }\end{array}$} \\
\hline \multirow{2}{*}{$\begin{array}{l}\text { Independent } \\
\text { Variables }\end{array}$} & \multicolumn{4}{|c|}{ Dependent variable: DLIMPT } \\
\hline & Coefficient & Std error & t-statistic & Prob. \\
\hline $\mathrm{C}$ & -12.6165 & 7.6787 & -1.6430 & 0.1129 \\
\hline DLIMPT(-1) & $0.3608^{* *}$ & 0.1323 & 2.7257 & 0.0115 \\
\hline DLGDP & 0.1933 & 0.2129 & 0.9081 & 0.3725 \\
\hline DLREER & 0.0520 & 0.1131 & 0.4441 & 0.6608 \\
\hline DLENDR & -0.0020 & 0.0208 & -0.1092 & 0.9139 \\
\hline DLOPEN & $1.2824^{* * *}$ & 0.1672 & 7.6666 & 0.0000 \\
\hline DLREM & -0.0827 & 0.0560 & 1.4774 & 0.1520 \\
\hline DLFINC & $1.018^{* *}$ & 0.4243 & 2.4009 & 0.0241 \\
\hline \multicolumn{5}{|c|}{ Diagnostic statistics } \\
\hline \multicolumn{2}{|l|}{ R-squared } & \multicolumn{3}{|l|}{0.89} \\
\hline \multicolumn{2}{|l|}{ Adj. R-squared } & \multicolumn{3}{|l|}{0.86} \\
\hline \multicolumn{2}{|c|}{ Durbin Watson Stat. } & \multicolumn{3}{|l|}{1.77} \\
\hline \multicolumn{2}{|l|}{ J-statistic } & \multicolumn{3}{|l|}{0.04} \\
\hline
\end{tabular}

Source: Authors computation from E-view 7, 2017

Note: ${ }^{* * *}, * *, *$ denotes significance at $1 \%, 5 \%$ and $10 \%$ respectively.

As a follow up to the startling revelation presented in table 5 above, it become empirically expedient to empirically ascertain whether consumption pattern of Nigerians favour import or locally manufactured goods. This becomes necessary as a result of empirical findings that migration depletes the labour force of labour sending countries. This often results to rise in labour cost in the labour sending countries. The resultant implication is wage rise that makes locally made goods to be expensive and makes import cheaper. In the final analysis, rational consumers prefer imported goods as against the locally made goods. To examine whether this phenomenon operates in Nigeria, model 3.4c is formulated. The result of the GMM estimate of the model is presented in table 4.11. Empirical estimate indicates that $89 \%$ change in the dependent variable can be explained by the independent variables, imports, economic growth, real exchange rate, lending rate, trade openness, remittance and consumption.

Estimated result show that one year lagged value of import is a positive determinant of current year import. Specifically, result indicate that a percentage change in the previous year import will culminate into 0.36 percentage change in current year import and the result is statistically significant a 5\% level. The coefficients of economic growth and exchange rate, positively related to import but statistically insignificant.

As expected, the coefficient of trade openness is positively related to import and statistically significant at $1 \%$ level. This implies that holding other variables constant, a percentage change in trade openness will result in 1.28 percentage change in imports.

The coefficient of remittance is negatively related to import but statistically insignificant. An interesting finding of this result is the positive and highly significant relationship observed between consumption and import. The implication is that holding other variables constant, a percentage change in consumption will result in 1.02 percentage point increase in imports.

The GMM estimate of direct relationship between inward remittances and productive investment show a negative relationship, thereby lending credence to Pure Atruism Theory of 
remittance. This finding is consistent with result of Hrushikesh(2008) and Okodua(2010). The inverse relationship found in the remittance - investment necessitated exploring the consumption channel. Results show that inward remittances have robust positive effect on consumption of Nigerians. This result is also in consonance with the findings of Agu(2009) and Sami and Mohammed(2012). This finding is not surprising, considering low output and consumption behavior of Nigerians that favour imports rather than locally manufactured goods. For a country like Nigeria with glaring evidence of Dutch Disease Syndrome and abysmal performance of the manufacturing sector of the economy, this result is likely to be the case as a result of huge infrastructural gap that hamper manufacturing sector capacity utilization.

In view of this observed phenomenon, it becomes necessary to examine the relationship between imports and consumption. The results actually confirm our thinking. In final consumption expenditure which includes consumption by households and government, overall impact of consumption on imports is found to be positive and highly significant at $1.0 \%$ level. Agu(2009) also had similar result in his study. In contrast, remittances have negative impact on imports, largely due to import variable that have raw materials import components. Indeed, it is likely that if imports of consumer goods be disaggregated from raw material imports, the impact of consumption on consumer imports could be profound. The consumption behaviour observed could also be the case of Dutch Disease Syndrome resulting from appreciation of real exchange rate caused by foreign exchange inflows.

Another finding from this study is the inverse relationship between remittance inflows and productive investment. Long years of huge remittance inflows into the Nigerian economy have not made commensurate positive impact on the Nigerian business climate.

This is not surprising, considering the high cost of doing business in Nigeria occasioned by huge infrastructural gap plaguing the Nigerian economy.

\section{CONCLUSION AND RECOMMENDATIONS}

A startling revelation of the study is the positive and highly significant relationship between remittance and consumption on one hand, and consumption and imports on the other hand. The result of this study actually lend credence to the findings of previous studies on the remittance-investment channel in other countries. For a country like Nigeria with documented evidence of unbridled consumption, low productive capacity and infrastructure decayed economy, this is more germane and relevant.

While household inward remittances to the Nigerian economy have been upward swing, the real sector has performed poorly. This could be attributed to the seeming resource transfer to consumption of imports arising from price differentials between locally manufactured goods and foreign imports. To plug this leakage, it becomes imperative for the Nigerian government to dismantle all bureaucratic bottlenecks that make cost of production high. It is imperative for the Nigerian government to stop subsidizing consumption such as proposed school feeding and fuel Subsidy and channel the resources to infrastructure development. This will in no doubt lower cost of production and hence price of locally manufactured goods.

\section{References}

Abdih, Y., Chami, R. Dagher, J., \& Montiel, P. (2012). Remittnaces and institutions. Are remittances a curse? World Development, 40(4), 657-666. 
Adams, R.H. (2005). International migration, remittances and the brain drain: A study of 24 labour-exporting countries. Policy Research Working Paper No. 2972. Washington, D.C: World Bank.

Adams, R.H., \& Page, J. (2005). Do international migration and remittances reduce poverty in developing countries? World Development, 33(10), 1645-1669.

Adams, R.H., Cuecuecha, A., \& Page, J. (2009). The impact of remittances on poverty and inequality in Ghana. World Bank, Policy Research Working Paper 4732.

Aggarwal, R., Asli, D.K., Peria, M., \& Soledad, M. P. (2006). Do workers' remittnaces promote financial development? World Bank Policy Research Working Paper No. 3957. Washington DC: World Bank. Retreived from http://ssrn.com/absract $=923264$

Agu, C. (2009). Remittances for growth: A two fold analysis of feedback between remittances, financial flows and the real economy in Nigeria. A paper Presented at the Econometric Society Conference July $8-10,2009$, Sheraton Hotel, Abuja.

Aseh, B.J. (1994). Emigration and its effects on the sending country: Available from george vernez. The rand corporation 1700 Main Street, Santa Monica. California.

Burney, M. (1989). A macro -economic analysis of the impact of workers remittances in Pakistan's economy in Rashid Amjad (Ed.) To the gulf and back: studies on The Economic Impact of Asian Labour Migration ILO Geneva.

Catrinesseu, N., Leon-Ledesina, M., Piracha. M., \& Quillin, B. (2006). Remittances, institutions, and economic growth. Discussion paper No.2139

Catteneo, C. (2008). International migration and poverty: A cross-country analysis. Available at:http://www.daglino.unimi.it/media/cataneo: Cristina.pdf

CBN, (2014). Annual reports and statement of acoounts. www.cbn.gov.ng

Chami, R. A., Barajas, T., Cosimano, C., Fullenkamp, C., Gapen, M., \& Montiel, P. (2008). Macroeconomic consequences of remittances. IMF Occasional Paper, No. 259.(Washington: International Monetary Fund)

Chilokwu, I.D.O; Olise, M.C., \& Ewuim, N.C. (2011). Protecting human rights of Nigerian migrants: The case of migrants' remittances enterprise for sustainable development in Nigeria. Kuwait Chapter of Arabian Journal of Business and Management Review. 1(1), 40-50.

Craig, J.C. (1982). More efficient estimation in the presence of heteroscedasticity of unknown form. Econometrica, 51(3), 751-63.

De Haas, H. (2007a). Impact of international migration on social and ecoomics development in Moroceans Sending regions: A review of the empirical literature. International Migration Institute, University of Oxford, Oxford.

Fayissa, B., \& Nsiah, C. (2008). The impact of remittances on economic growth and development in Africa. Department of economics and finance, working paper series, available online at:http: ideas.repec.org./p/ints/wpaper/2000802.html.

Giuliano, P., \& Ruiz-Arranz, M., (2009). Remittances, financial development and growth. Journal of Development Economics, 90(1), 144-152.

Glytsos, N.P (2002a). A macroeconometric model of the effects of migrant remittances in Mediterrean countries. In Isirageldm (ed.). Human Capital Population Economics in the Middle East, Cairo. Egypt: An Economic Research Forum Edition, the American University in Cairo Press. 300-325.

Glytsos, N.P (2002b). Dynamic effects of migrant remittances on growth: An Econometric Model with an application to Mediterrean countries. Discussion paper, No. 74 0505014, Labour and Demography. Economics Working Paper Archive at Washington University in St. Louis.

Glytsos, N.P. (2002c). A model of remittance determination applied to Middle East and North African countries. Discussion Paper, No. 730505016, Labour and Demography. Economics Working paper Achieve at Washington University in St. Louis.

Gupta, S., Pattillo., C., \& Wagh, S. (2009). Effect of remittances on poverty and financial development in SubSaharan Africa. World Development, 37(1), 104-115.

Habib, A., (1985). Economic cnsequences of international migration for sending countries: Review of evidence from Bangledesh. (Doctoral dissertation, University of Newcastle, Australia).

Hansen, L.P. (1982). Large sample properties of generalized method of moment estimators Econometrica, 50(4), 1029-1054. 
Hatemi, J.A. (2008). Tests for co integration with two unknown regime shifts with an application to financial market integration. Empirical Economics. 35, 497-505.

Hrushikesh, M. (2008). Do remittances impact the economy? Some empirical evidences from a developing economy. Available on www.cds.edu.

Kalim, R., \& Shahbaz, M. (2009). Remittances and poverty nexus: Evidence from Pakistan. International Research Journal of Financial Economics, 10(3), 46-59.

Kenedy, P.A. (2003). A Guide to Econometrics. The MIT Press Combridge, Masschusetts.

Kim, S. (1983). Economic analysis of Korean manpower migration. Sogang University Journal of Economics and Business. 3 - 6.

Kim, S. (1986). Labour migration from Korea to the Middle East: Its trends and impact on the Korean economy. In Arnold F. and Nasra M. (Eds), Asian labour migrations. Pipeline to the middle east, westview, boulder, $163-176$

Newey, W.K., \& West, K.D. (1987). A simple positive semi-definie, heteroscedasticity and autocorrelation consistent covariance matrix. Econometrica, 55(3), 703-08.

Ojapinwa, T.V. \& Odekunle, L.A. (2013). Workers' remittance and their effect on the level of investment in Nigeria: An empirical analysis. International Journal of Economics and Finance. 5(4),89-99.

Okodua, H. (2010). Workers' remittances and economic growth in selected Sub-Saharan African countries. A PhD Thesis Submitted to the Department of Economics. Covenant University, Ota.

Olowa, O.W., Awoyemi, T.T., Shittu, M.A., \& Olowa, O.A. (2013). Effects of remittances on poverty among rural households in Nigeria. European Journal of sustainable Development 2(4), 263-284.

Olubiyi, E.A. (2013). Workers' remittances, governance institution and private investment in Nigeria. The Review of Finance and Banking 6(1), 63-81.

Sami M., \& Mohamed B.M I. (2012). Through which channels can remittances spur economic growth in MENA Countries? International Journal of Economic Perspectives, 6(1), 55-81.

Stark, O. (1991). The migration of labour. Cambridge. Cambridge University Press.

Stark, O., \& Bloom, D.E. (1985). The new economics of labour migration. American Economic Review, 75(2), 173178.

Stock, J.H., \& Watson, M.W. (2007). Introduction to econometrics. New York. Pearson.

Tansel, A., \& Yasar, P. (2010). Macroeconomic impact of remittances on output growth: Evidence from Turkey. Migration Letters. 7(2), 132-143.

Taylor, J.E. (1999). The new economics of labour migration and the role of remittances in the migration process. International Migration, 37(1), 63-88.

Thanh, L. (2008). Trade, remittnaces, institutions and economic growth. Macro Economics Research Group.

White, H. (1984). Asymptotic theory for econometrics. Orlando Fla. Academic Press.

World Bank, (2015). World Development Indicators 2014. Washington, D.C.: World Bank, Washington D.C. USA.

World Bank, (2012). World Development Indicators 2012. Washington, D.C. World Bank.

World Bank, (2013). World Development Indicators (WDI): online Database, The World Bank, Washington, D.C. USA.

Ziesemer, T. (2007). Workers remittances and growth: The phyiscal and human capital channels. United Nations University Working paper Series. 